\title{
De economische betekenis van nationale veiligheidsrisico's
}

\author{
Peter van Bergeijk \& Marcel Mennen
}

\begin{abstract}
De economische analyse van (potentiële) rampen is belangrijk om inzichtelijk te maken welke investeringen in welke preventie van welke rampen efficiënt zijn en welke niet. Er is weinig specifiek Nederlands onderzoek op dit terrein. Beleidsmakers stellen prioriteiten op basis van kosten en baten. Dit artikel biedt een overzicht van internationaal onderzoek en laat zien hoe dit handvatten kan bieden om de economische impact van uiteenlopende rampen te schatten. Hierbij wordt aansluiting gezocht bij de Nationale Risicobeoordeling (NRB), waarin schillende soorten rampen, crises en dreigingen worden geanalyseerd met scenario's die volgens een vaste multidisciplinaire systematiek worden beoordeeld om effecten onderling te kunnen vergelijken. De economische impact is een van de beoordelingscriteria. We bespreken voor- en nadelen van toegepaste ramingsmethoden aan de hand van een aantal praktijkvoorbeelden op uiteenlopende scenario's uit de NRB.
\end{abstract}

\section{Inleiding}

'(...) Intussen ontstaan er spanningen tussen de EU en een ander land buiten de EU. In het land nemen de spanningen tussen bevolkingsgroepen toe. Dit leidt tot ongeregeldheden die hard worden neergeslagen. Verschillende gebeurtenissen volgen elkaar op: de EU treft sancties (...)' (uit de Nationale Risicobeoordeling 2011: het scenario Crisis buiten de EU; Mennen 2012).

De Nationale Risicobeoordeling (NRB) analyseert verschillende soorten rampen, crises en dreigingen met behulp van scenario's die volgens een vaste multidisciplinaire systematiek worden beoordeeld (Mennen 2012). Het gaat om rampen van allerlei aard: overstromingen, pandemieën, chemische en nucleaire rampen, maar ook terroristische aanslagen, grootschalige onlusten en uitval van vitale sectoren door cyber hacktivisten. Deze analyse maakt deel uit van de strategie Nationale Veiligheid (Ministerie van Binnenlandse Zaken en Koninkrijksrelaties 2007), die tot doel heeft rampen en crises zo veel mogelijk te voorkomen of de gevolgen ervan te minimaliseren. De nationale veiligheid is in het geding als één of meer vitale belangen of de kernwaarden van onze samenleving worden bedreigd. Die vitale belangen zijn territoriale veiligheid, fysieke veiligheid, ecologische veiligheid, sociale en politieke stabiliteit en economische veiligheid. Deze zijn in de NRB systematiek geoperationaliseerd (meetbaar gemaakt) in tien impactcriteria. Over economische veiligheid is in Nederland relatief weinig onderzoek gedaan. Dit artikel beoogt die lacune te vullen en aan economen en niet-economen handvatten te bieden voor het kwantificeren van de economische impact. 
In de beoordelingssystematiek van de NRB zijn vitale belangen geoperationaliseerd in tien criteria, die gezamenlijk de impact (gevolgen) bepalen ( Ministerie van Binnenlandse Zaken en Koninkrijksrelaties 2009). De systematiek wordt gebruikt om de impact en de waarschijnlijkheid van de scenario's, die de verschillende soorten rampen, dreigingen en crises beschrijven, te beoordelen: het scoren. De scenario's en de scores worden gebruikt om capaciteiten te benoemen, prioriteiten te stellen en beleid te formuleren om Nederland zo goed mogelijk voor te bereiden op rampen en dreigingen. Een van de criteria op basis waarvan de zwaarte van verschillende scenario's wordt bepaald, is de economische impact.

Wanneer economische nationale veiligheidsrisico's zich materialiseren, spreekt men van rampen (Hyndman \& Hyndman 2006). Dergelijke rampen zijn economisch relevant wanneer ze een verstoring van economische processen veroorzaken en daarmee een sterke invloed kunnen hebben op de welvaart en het welzijn van burgers en bedrijven. Ter bepaling van de gedachten wordt in tabel 1 op basis van gegevens van Barro \& Jin (2009) een overzicht gegeven van de frequentie van economische rampen vanuit een historisch perspectief. Op basis van dit overzicht blijkt Nederland te kunnen worden geclassificeerd als een land met een gemiddelde frequentie van economische contracties. De gemiddelde frequentie gemeten over alle landen is $8,8 \%$, met een standaarddeviatie van 4,1 . De frequentie voor Nederland is 7,6\%. Gegevens van het Centraal Bureau voor de Statistiek (CBS) laten zien dat de contracties gedurende de Grote Depressie (in de jaren dertig van de vorige eeuw) en de Grote Recessie (2008-heden) niet voldoen aan de norm van Barro en Jin: in de naoorlogse periode hebben zich volgens deze norm dus (nog) geen economische rampen in Nederland voltrokken. Mogelijk verklaart dit de magere aandacht voor economische aspecten van rampen.

De bijdrage van de economische wetenschap vanuit het perspectief van de NRB bestaat uit het inzichtelijk maken en kwantificeren van deze invloed. Beleidsmakers willen weten welke investeringen in welke preventie van welke rampen efficient zijn en welke niet. ${ }^{1}$ De economische analyse is dan noodzakelijk, omdat de omvang van de economische schade een van de elementen is bij het stellen van preventieprioriteiten. Soms is de economische analyse overigens ontnuchterend, bijvoorbeeld wanneer de kosten van preventie de baten in termen van voorkomen schade overtreffen en preventie daarom op economische gronden inefficiënt is. Er kunnen dan andere, bijvoorbeeld politieke en maatschappelijke, overwegingen zijn om desondanks toch tot preventie over te gaan.

Dit artikel wordt mede gemotiveerd door de (te) sterke mate van academische specialisatie (Alexander 1997). Hierdoor verschilt de methodologie voor het bepalen van de kosten en baten van rampen en preventie per rampdomein. Daar komt bij dat er twee duidelijk onderscheiden domeinen zijn: de natuur(lijke) rampen - waaronder exceptionele weersomstandigheden, gezondheidsbedreigingen, aarden heelalschokken, ziekten - en de rampen van menselijke makelij, zoals terrorisme, grootschalige rellen, (economische) oorlogvoering en politieke verwikkelin-

1 In dit artikel beperken we ons tot de kosten van (natuur)rampen en komen we niet toe aan de afweging ten opzichte van de baten van preventie en/of mitigatie; vergelijk Romijn \& Renes 2013. 
Tabel 1: $\quad$ Frequentie van substantiële economische contracties (reële daling bnp per hoofd met ten minste 5\%) sinds het begin van de negentiende eeuw

\begin{tabular}{ll}
\hline Frequentie & Landen \\
\hline $5 \%$ van de jaren of minder & $\begin{array}{l}\text { Denemarken, Italië, Spanje, Verenigd Koninkrijk, Zuid- } \\
\text { Afrika, Zweden }\end{array}$ \\
Van 5\% tot en met 10\% van de jaren & $\begin{array}{l}\text { Australië, België, Brazilië, Canada, Duitsland, Chili, Fin- } \\
\text { land, Frankrijk, IJsland, India, Indonesië, Japan, Mexico, } \\
\text { Nederland, Noorwegen, Oostenrijk, Peru, Filippijnen, } \\
\text { Portugal, Taiwan, Verenigde Staten, Zwitserland }\end{array}$ \\
Van 10 tot en met I5\% van de jaren & $\begin{array}{l}\text { Egypte, Griekenland, Maleisië, Nieuw-Zeeland, Sri Lanka, } \\
\text { Zuid-Korea }\end{array}$ \\
Meer dan 15\% van de jaren & Argentinië, Turkije, Uruguay, Venezuela \\
\hline
\end{tabular}

gen. Voor een integrale afweging (bijvoorbeeld ten behoeve van het stellen van preventieprioriteiten) zoals die in de NRB centraal staat, is het echter gewenst dat het volledige spectrum van benaderingen in beeld wordt gebracht, zodat de methodologie 'all hazard' kan worden toegepast. Er zijn nog (te) weinig studies die een gemeenschappelijke methodologie toepassen op een brede waaier aan veiligheidsdomeinen. Dit artikel wil een eerste aanzet geven tot een - economische methodologie die over de grenzen van de specialismen kan worden toegepast en biedt daarnaast een staalkaart ('handvatten') van gehanteerde methoden in recente NRB-scenario's.

De opbouw van dit artikel is als volgt. In paragraaf 2 wordt een kostenraamwerk besproken, waarbij onderscheid is gemaakt tussen directe en indirecte kosten. Daarnaast wordt gekeken naar de invloed op het tempo van economische groei en wordt de noodzaak van een brede benadering duidelijk gemaakt. In paragraaf 3 wordt een overzicht van ramingstechnieken, op micro- (bedrijven en gezinnen) en macroniveau (nationale economie), gegeven. In een aantal NRB-scenario's zijn deze technieken al toegepast en daarvan worden in dit artikel diverse praktijkvoorbeelden gegeven. In paragraaf 4 komen de robuustheid en onzekerheden van economische benaderingen aan bod. In paragraaf 5 wordt samengevat en worden enige conclusies getrokken.

\section{Kostenraamwerk}

In de macro-economische literatuur wordt een onderscheid gemaakt tussen directe en indirecte kosten. Beide kostencomponenten zijn relevant, maar er zijn verschillen in tijdsduur, reikwijdte en beheersbaarheid. In deze paragraaf bespreken we de verschillen op hoofdlijnen. Daarnaast kijken we naar de invloed van rampen op het tempo van economische groei. 
Tabel 2: $\quad$ Doden, gewonden en schade door natuurrampen (mondiaal) 1970-2002

\begin{tabular}{lllllll}
\hline & \multicolumn{2}{l}{ Doden (duizenden) } & \multicolumn{2}{l}{$\begin{array}{l}\text { Gewonden } \\
\text { (duizenden) }\end{array}$} & \multicolumn{2}{l}{$\begin{array}{l}\text { Schade in miljard \$ } \\
\text { (prijzen 1995) }\end{array}$} \\
\hline Droogte & 878 & $32 \%$ & 0 & $0 \%$ & 61 & $6 \%$ \\
Wind/storm & 612 & $22 \%$ & 520 & $19 \%$ & 280 & $28 \%$ \\
Aardbeving & 574 & $21 \%$ & 1089 & $40 \%$ & 301 & $31 \%$ \\
Hongersnood & 232 & $8 \%$ & & & 0,1 & $0 \%$ \\
Overstroming & 210 & $8 \%$ & 982 & $36 \%$ & 278 & $28 \%$ \\
Epidemie & 154 & $6 \%$ & 80 & $3 \%$ & & \\
Vulkaan & 26 & $1 \%$ & 8 & & 6 & $1 \%$ \\
Aardverschuiving & 25 & $1 \%$ & 8 & & 4 & $0 \%$ \\
Hittegolf & 21 & $1 \%$ & 10 & & 28 & $3 \%$ \\
Overig & 4 & & 2 & & 29 & $3 \%$ \\
Totaal & 2736 & $100 \%$ & 2700 & $100 \%$ & 986 & $100 \%$ \\
\hline
\end{tabular}

Bron: Yang (2006).

\subsection{Directe kosten}

De directe kosten kunnen worden gedefinieerd als de waarde van de beschadiging en vernietiging die optreedt door de ramp. ${ }^{2}$ Dikwijls kan de waarde van de teloorgegane goederen, diensten en productiemiddelen relatief eenvoudig worden bepaald, namelijk indien er markten bestaan waarop dergelijke zaken worden verhandeld of indien er ramingen zijn van de uitgaven die nodig zijn om beschadigingen te repareren. Ook het kwantificeren van verstoringen van de bedrijfsvoering van ondernemingen is relatief eenvoudig; op een heel basaal niveau gebeurt dat al in de Nationale Rekeningen door rekening te houden met werkdageffecten (verschillen in het aantal gewerkte dagen per maand). Er zijn echter ook beschadigingen en vernietigingen die niet kunnen worden geneutraliseerd door middel van reparatie of vervanging via de markt. Voorbeelden zijn: doden, gezondheidsverlies, schade aan ecosystemen en verlies aan burgervrijheden. In deze gevallen behoort reparatie of vervanging niet tot de mogelijkheden. Dit wil niet zeggen dat deze kosten er niet toe doen; wel is het veel ingewikkelder en dikwijls omstreden om deze verliezen in geld te waarderen.

Tabel 2 geeft ter bepaling van de gedachten op mondiaal niveau een overzicht van doden, gewonden en directe schade van natuurrampen in een periode van ruim dertig jaar. De tabel is geordend op aantallen doden. De grootste kostenposten zijn aardbevingen, overstromingen en stormen.

2 Belangrijk is dat er soms geen beschadiging is. Een voorbeeld is dat communicatie-infrastructuur kan uitvallen zonder metterdaad beschadigd te raken; er is dan toch sprake van een economisch verlies (zie bijv. Pellinga, Özerdemb \& Barakatb 2002). 


\subsection{Indirecte kosten}

De indirecte kosten treden op bij effecten van de tweede (en hogere) orde; het zijn geen directe gevolgen van een ramp en ze hebben meestal betrekking op een langere periode waarin negatieve consequenties worden veroorzaakt door ontregeling van economische en maatschappelijke processen ten gevolge van de ramp. Dikwijls zijn de indirecte kosten uiteindelijk groter dan de directe kosten en daarnaast worden ze sterker beïnvloed door beleidsreacties.

Anders dan bij de directe kosten is het bij indirecte kosten mogelijk dat ze optreden buiten het feitelijke rampgebied. De vernietiging van een spoorbaanvak door een lokale overstroming is een voorbeeld van een directe kostencomponent die indirecte kosten op nationale schaal tot gevolg heeft in de vorm van het uitvallen van transportmogelijkheden over dat baanvak. ${ }^{3}$ Deze indirecte kosten zijn deels afhankelijk van het tempo en de doelmatigheid waarin herstelwerkzaamheden worden verricht en zijn ook daarom altijd omgeven met grotere onzekerheidsmarges dan de directe kosten.

Ook zijn er indirecte kosten die optreden doordat burgers, bestuurders en bedrijven reageren op een ramp. Beslissingen om een land of stad aan te doen worden teruggedraaid, vooral als er een samenloop van veiligheidsrisico's is (Larsen 2011). Het niveau, de locatie en de samenstelling van nieuwe investeringen worden aangepast ( $\mathrm{Li}$ 2006). Veiligheidskosten en grenscontroles belemmeren internationale handel en transport (Nitsch \& Schumacher 2004), en bestuurlijke reacties leiden tot verschuivingen in het budget, waardoor andere overheidsdiensten onder druk komen te staan, en kunnen zelf excessief zijn (Mueller \& Stewart 2011). De economische analyse is belangrijk om de kosten van deze gedragingen in kaart te brengen.

Een belangrijk thema is het feit dat er geen consensus is over de invloed van rampen op het tempo van de economische groei (Van Bergeijk \& Lazzaroni 2013). Voor een deel is dit een reflectie van het feit dat alle rampen weliswaar in eerste instantie de groei vertragen door een verstoring van de maatschappelijke processen en kapitaalvernietiging, maar dat sommige rampcategorieën de groei ten goede kunnen komen omdat de kapitaalgoederenvoorraad wordt hersteld met nieuwere en betere kapitaalgoederen (Kim 2010). Hierbij is er een afruil tussen de ernst van de ramp en het groeipotentieel. Kleine natuurrampen werken bijvoorbeeld mogelijkerwijs als een groei-impuls, maar grote rampen doen dat niet (Loayza, Olaberría, Rigolini \& Christiaensen 2009). Het is echter ook mogelijk dat de empirische dubbelzinnigheid wordt veroorzaakt door meet- en registratieproblemen en een exclusieve focus op het bruto nationaal product (bnp). Het is de vraag of een stroomgrootheid als het bnp wel een goed beeld geeft van wat er gebeurt in een economie die door een ramp wordt getroffen. Door een ramp wordt de kapitaalgoederenvoorraad verkleind (dit kan betrekking hebben op alle

3 Rampen trekken zich bovendien niets van landsgrenzen aan. Sahin (2011) berekent dat circa een zesde van de impact van een ramp buiten de landsgrenzen optreedt. Rampen in andere landen kunnen zo een bedreiging vormen van de nationale veiligheid. De buitenlandse effecten van rampen die zich in Nederland voltrekken worden niet meegenomen in de economische impact in de NRB-systematiek, wel in een criterium dat het internationaal imagoverlies van ons land representeert. 


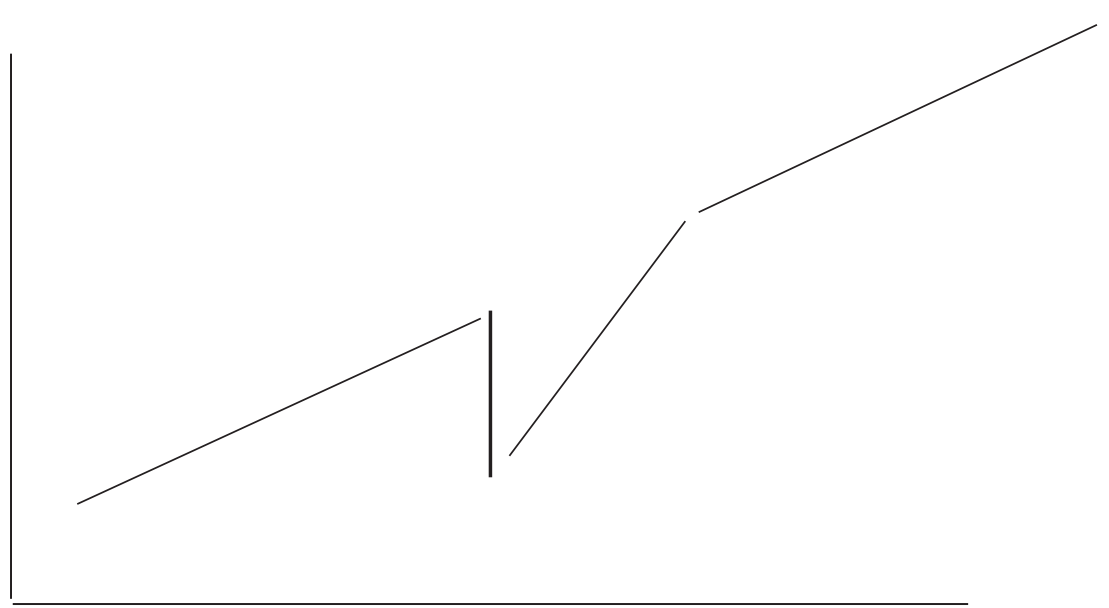

Groeivoet BNP

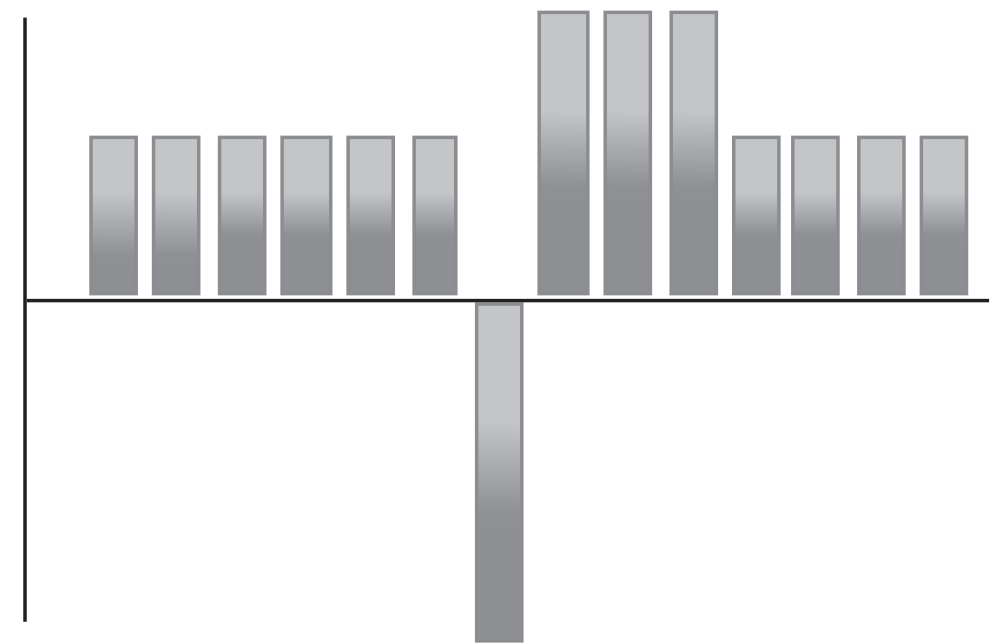

Figuur 1 Gestileerde weergave van niveau en groeivoet van het bnp na een ramp

vormen van kapitaal, inclusief natuurlijke hulpbronnen en menselijk kapitaal). $\mathrm{Na}$ de ramp moet de kapitaalgoederenvoorraad worden gereconstrueerd en die inspanningen vertalen zich in een hogere groeivoet van het bnp. Ook indien een ramp alleen maar leidt tot verstoring van het productieproces (dus zonder kapitaalvernietiging), treedt na een aanvankelijke daling een tijdelijke groeiversnelling op totdat de economie zich weer op het langetermijngroeipad bevindt. Over de periode na de ramp meet men dan een hogere groei (figuur 1). 


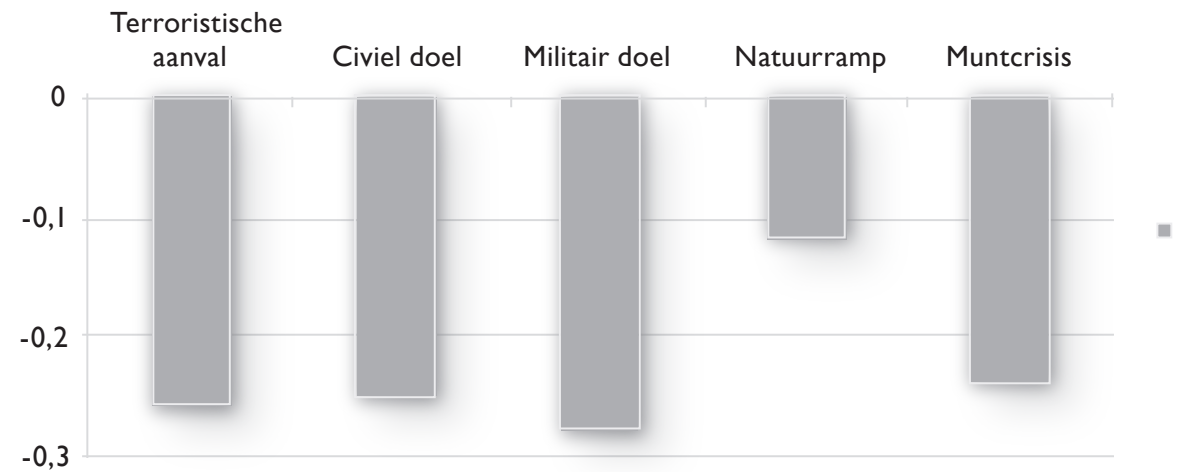

Figuur 2 Invloed van nationale veiligheidsrisco's op de reële groeivoet van het bnp per hoofd van de bevolking

De implicatie is dat de maatschappelijke kosten van een ramp moeten worden gedefinieerd hetzij aan de hand van de vernietiging van menselijk, natuurlijk en fysiek kapitaal, hetzij aan de hand van de afwijking van het langetermijngroeipad (concreet betekent dit dat in de jaren met hogere groei in figuur 1 nog steeds een welvaartsverlies optreedt omdat de economie zich nog onder dat groeipad bevindt). ${ }^{4}$

In figuur 2 is de gemiddelde groeivertraging volgens de studie van Tavares (2004) weergegeven. Dit is een van de weinige studies die een all hazard- (of beter: multi hazard-) benadering kiest. Daar waar de frequentie van natuurrampen groter is dan de frequentie van door mensen gecreëerde rampen, is de impact op het groeitempo juist groter voor de man made hazards. ${ }^{5} \mathrm{Bij}$ natuurrampen is de gemiddelde daling van de middellange groei 0,1 procentpunt per jaar; bij muntcrises en terroristische aanslagen ligt dit tussen de 0,2 en 0,3 procentpunten.

\subsection{Noodzaak van een brede benadering}

Het ramen van productieverliezen start bij de identificatie van de kapitaalgoederen die door de ramp verloren of beschadigd raken. Hierbij moet in het kader van de beoordeling van nationale veiligheidsrisico's een brede definitie worden gehanteerd voor kapitaal, zodat rekening wordt gehouden met schade die optreedt aan fysieke activa (machines, fabrieken, infrastructuur), menselijke activa (opgebouwde kennis en kunde van de beroepsbevolking), natuurlijke activa (land, hulpbronnen en natuur) en immateriële activa (patenten, reputatie, psychologische problemen) (zie Popp 2006).

4 De kosten of het 'verlies' zijn gelijk aan het oppervlak van de driehoek die wordt gevormd door de denkbeeldige lijn van de doorgetrokken lijn voor het bnp en de punt naar beneden.

5 Hierbij is de nationale context bepalend. Aardschokken in Italië zijn natuurlijk; in Groningen zijn ze van menselijke makelij. 
Deze opsomming maakt al duidelijk dat de invalshoek niet louter (bedrijfs)economisch kan zijn, maar ook burgers en overheden betreft. In theorie is de raming van deze kosten rechttoe rechtaan want het waardeverlies van de kapitaalgoederen komt in principe overeen met de contant gemaakte waarde van toekomstige productie-uitval. In de praktijk zijn er echter nogal wat haken en ogen, omdat er ook sprake kan zijn van effecten die niet door de markt worden verdisconteerd: dit is bijvoorbeeld het geval voor de openbare dienstverlening en de publieke infrastructuur. In zulke gevallen zullen de via marktprijzen bepaalde kosten de maatschappelijke kosten onderschatten.

\section{Ramingstechnieken}

Er is al een groot scala aan studies en methoden beschikbaar die kunnen helpen bij het opstellen van een prospectieve raming van de economische kosten en impact van veiligheidsscenario's zoals in de NRB (Van der Veen 2004; Greenberg, Lahr \& Mantell 2007; zie tabel 3). In deze sectie bespreken we deze methoden en daarbij gebruiken we concrete voorbeelden die zijn ontleend aan praktijkvoorbeelden uit recente NRB-scenario's. In de eerste plaats laten we daarbij zien wat kan en al gebeurt. Hierbij is het aandachtspunt het gebruik en de geschiktheid van de methode (bijvoorbeeld of deze inzicht geeft in indirecte of directe kosten en wat de voor- en nadelen zijn). Ten tweede bekijken we of en hoe de methode past in een all hazard-benadering, mede met het oog op het identificeren van mogelijkheden voor nader onderzoek en methodeontwikkeling. We hebben de bespreking georganiseerd per methode. Achtereenvolgens komen aan bod: analyses van microgegevens, berekeningen op basis van de Nationale Rekeningen, reacties van financiële markten en vertrouwensindicatoren, internationaal vergelijkende onderzoeken en (macro-)econometrische modellen.

\subsection{Microgegevens}

Bij microgegevens gaat het om gegevens die beschikbaar zijn op het niveau van individuele burgers en bedrijven en die inzicht kunnen geven in zowel de directe als indirecte kosten op individueel niveau. Een voordeel van deze gegevens is de grote mate van detaillering; een nadeel is dat een analyse van microgegevens kwetsbaar is voor de samenstellingsfout ( fallacy of composition), waardoor een maatschappelijk effect (bijvoorbeeld het indirecte macro-effect) zowel onder- als overschat kan worden. Microdata zijn nog niet gebruikt in de economische analyse van nationale veiligheidsrisico's, maar hiervoor bestaan wel degelijk mogelijkheden. Deze gegevens worden in Nederland verzameld door het CBS; vaak gaat het hierbij om gekoppelde bestanden, bijvoorbeeld van de Belastingdienst en de uitvoerstatistieken. Een extern afgedwongen reductie van de buitenlandse handel kan dan vertaald worden naar regionale en zelfs lokale impact. ${ }^{6}$ Enquêtes die inzicht bieden in de kosten van de uitval van publieke diensten zijn dikwijls al

6 Möhlmann (2013, 11-13) brengt voor 2005 met behulp van microdata de regionale heterogeniteit van het uitvoeraandeel in de productie in kaart op het niveau van COROP-regio's. 
Tabel 3: Overzicht van ramingsmethoden

\begin{tabular}{|c|c|c|c|c|c|}
\hline & Microdata & $\begin{array}{l}\text { Nationale } \\
\text { Rekeningen }\end{array}$ & $\begin{array}{l}\text { Financiële } \\
\text { markten }\end{array}$ & $\begin{array}{l}\text { Internatio- } \\
\text { naal com- } \\
\text { paratief }\end{array}$ & Macro-modellen \\
\hline $\begin{array}{l}\text { Directe } \\
\text { kosten }\end{array}$ & $\mathrm{Ja}$ & $\mathrm{Ja}$ & $\begin{array}{l}\text { Alleen geheel van } \\
\text { directe en indi- } \\
\text { recte effecten }\end{array}$ & $\mathrm{Ja}$ & $\begin{array}{l}\text { Vormen meestal } \\
\text { de impuls }\end{array}$ \\
\hline $\begin{array}{l}\text { Indirecte } \\
\text { kosten }\end{array}$ & $\mathrm{Ja}$ & $\begin{array}{l}\text { Via tabel } \\
\text { onderlinge } \\
\text { leveringen }\end{array}$ & & $\mathrm{Ja}$ & $\mathrm{Ja}$ \\
\hline Sterkte & $\begin{array}{l}\text { Individuele } \\
\text { data }\end{array}$ & $\begin{array}{l}\text { Consistentie; } \\
\text { beschikbaar- } \\
\text { heid }\end{array}$ & $\begin{array}{l}\text { Snelle informatie- } \\
\text { verwerking; dag- } \\
\text { cijfers }\end{array}$ & $\begin{array}{l}\text { Inzicht in } \\
\text { land-speci- } \\
\text { fieke facto- } \\
\text { ren + sprei- } \\
\text { ding }\end{array}$ & $\begin{array}{l}\text { Gedragseffecten } \\
\text { Veel ervaring in } \\
\text { beleid }\end{array}$ \\
\hline Zwakte & $\begin{array}{l}\text { Maatschap- } \\
\text { pelijk } \\
\text { (totaal) } \\
\text { effect } \\
\text { (falacy of } \\
\text { comosition) }\end{array}$ & $\begin{array}{l}\text { Geen gedrags- } \\
\text { effecten }\end{array}$ & $\begin{array}{l}\text { Overreactie en } \\
\text { onder-reactie lei- } \\
\text { den tot ver- } \\
\text { keerde inschat- } \\
\text { ting }\end{array}$ & $\begin{array}{l}\text { Unieke } \\
\text { risico's }\end{array}$ & $\begin{array}{l}\text { Toegesneden op } \\
\text { economie; moeilij- } \\
\text { ker toepasbaar op } \\
\text { niet-economische } \\
\text { problemen }\end{array}$ \\
\hline $\begin{array}{l}\text { All hazard } \\
\text { toepasbaar }\end{array}$ & Ja & $\mathrm{Ja}$ & $\mathrm{Ja}$ & $\mathrm{Ja}$ & Beperkt \\
\hline $\begin{array}{l}\text { All hazard } \\
\text { toegepast }\end{array}$ & Nee & Beperkt & $\mathrm{Ja}$ & Beperkt & Nee \\
\hline
\end{tabular}

voorhanden bij toezichthouders zoals de Energiekamer, die dergelijke gegevens gebruiken om kosten (en daarop gebaseerde boetes) van netwerkuitval te bepalen.

\subsection{Nationale Rekeningen en tabellen van onderlinge levering}

De Nationale Rekeningen zijn de boekhouding van de Nederlandse economie die door het CBS wordt opgesteld en vormen als zodanig een belangrijk vertrekpunt om de orde van grootte van effecten te bepalen. Een belangrijk bijproduct zijn de tabellen van onderlinge levering (de input-outputtabellen). Deze tabellen laten de doorwerking zien van een probleem dat ontstaat in één sector en zich verspreidt naar andere sectoren omdat afnemers en/of toeleveranciers vervolgens in problemen komen (Rose, Benavides, Chang, Szczeniak \& Lim 1997; Santos \& Haimes 2004; Okuyama \& Chang 2004; Santos 2006). Dergelijke modellen kunnen verder worden uitgebouwd tot een Social Accounting Matrix (zie bijvoorbeeld Cole 1995), waarmee macro-economische relaties kunnen worden verdiept. Een voordeel van deze gegevens is dat ze gebaseerd zijn op productiestatistieken en meestal goed gebruikt kunnen worden om de ontwikkeling op korte termijn snel in kaart te brengen. Een nadeel is dat gedragseffecten buiten beeld blijven (het vervangen van het ene soort product door een ander soort product, al dan niet op basis van veranderende relatieve prijzen) en dat de technische coëfficiënten bij ingrijpende (prijs)schokken tamelijk instabiel blijken te zijn. Het toepassingsbe- 
reik van deze benaderingen is groot en omvat zowel natuurlijke veiligheidsrisico's als rampen van menselijke oorsprong.

\section{Handvat: Werkdagenbenadering bij ernstige grieppandemie (uit de NRB 2011)}

In de NRB 2011 is een scenario 'Ernstige grieppandemie' ontwikkeld en beoordeeld. Om de economische impact te bepalen zijn de macro-economische effecten berekend op basis van de correctiefactor die het CBS toepast in de ramingen voor de Nationale Rekeningen voor verschillen in het aantal werkdagen. Voor dit scenario is berekend dat een afname van het aantal gewerkte dagen met 2,38 - gebaseerd op een schatting van het aantal zieken en de ziekteduur met het SEIR-model (Lugnèr, Van Boven, De Vries, Postma \& Wallinga 2012) - leidt tot een daling van het bruto binnenlands product (bbp) met $0,12 \%$ tot $0,24 \%$, oftewel 700 tot 1400 miljoen euro. Er is ook een alternatieve berekening gemaakt met een methode van het Congressional Budget Office van de Verenigde Staten (2005, technische appendix).

\subsection{Analyse van reacties van financiële markten en vertrouwensindicatoren}

Financiële markten kunnen snel informatie verwerken en brengen de inzichten van experts tot uitdrukking door middel van de ontwikkeling van de aandelenkoersen. Deze markten zijn efficiënt en verwerken de beschikbare informatie razendsnel; de gegevens zijn op dagbasis aanwezig. Hiervan kan bijvoorbeeld gebruik worden gemaakt om de orde van grootte van een gebeurtenis snel in te schalen. Een voorbeeld is de studie van Shaw (2011), die uiteenlopende gebeurtenissen (tsunami, terrorisme, aardbeving, financiële crisis) all hazard vertaalt naar een grootteklasse. Een nadeel is dat markten dikwijls overreageren, zeker wanneer het gebeurtenissen met een lage frequentie en een grote individuele zichtbaarheid betreft. De bevindingen van Nahuis (2001) ondersteunen deze kanttekening. In zijn all hazard-benadering staat de invloed op het consumenten- en producentenvertrouwen van zowel internationale als nationale intentionele en niet-intentionele gebeurtenissen centraal. Die invloed is er wel en hij is significant: mensen worden pessimistischer van rampen. Maar de vertaling naar groei en productie is volgens Nahuis niet aantoonbaar: de gedragsaanpassing die men zou verwachten is dus tenminste minder sterk en komt niet altijd tot uiting in de economische impact. 


\section{Handvat: Wapenbeheersing falende staat (uit de NRB 2012)}

In het scenario 'Wapenbeheersing falende staat' uit de NRB 2012 (Mennen 2013) hebben het ontdekken van illegaal getransporteerde atoomwapens in westerse havens en de tijdelijke afsluiting van die havens een negatieve uitwerking op de economie. In het scenario treedt een daling van aandelenkoersen met $20 \%$ op. Varianten voor zo'n daling van het Centraal Planbureau (2011) laten slechts marginale invloeden zien. Bovendien vertonen markten overreacties, zeker wanneer het gebeurtenissen met een lage frequentie betreft. In dit scenario leidt de gebeurtenis tot een beperkte daling van het inkomen per hoofd van de bevolking. Andere effecten zijn aanwezig, maar van een veel kleinere orde en verwaarloosbaar.

\section{4 (Inter)nationaal vergelijkende analyses}

Een belangrijke bron voor ramingen wordt gevormd door internationaal vergelijkend onderzoek, zowel waar het studies betreft die betrekking hebben op eenzelfde soort veiligheidsrisico (Gorden e.a. 2004) als waar het gaat om studies die betrekking hebben op een palet aan veiligheidsrisico's (Nahuis 2001; Tavares 2004). Het voordeel van internationaal vergelijkende onderzoeken is dat inzicht ontstaat in zowel de te verwachten spreiding (onzekerheid) van de economische effecten als landspecifieke karakteristieken die de incidentie, de impact en de kosten en baten van preventie mede kunnen bepalen. Een nadeel is dat nieuwe (dikwijls: unieke) risico's vaak nog niet in voldoende landen zijn opgetreden om zinvol te kunnen worden geanalyseerd in een internationaal comparatief kader. ${ }^{7}$

\section{Handvat: Grootschalige onlusten (uit de NRB 2012)}

Voor de NRB 2012 is een scenario 'Grootschalige onlusten' ontwikkeld, waarin - na een periode van geleidelijk toenemende ondermijnende en criminele activiteiten door verschillende groepen - in enkele dagen op veel plaatsen in het land forse rellen plaatsvinden met ernstige vernielingen, plunderingen en gewelddadige confrontaties met de hulpdiensten. Om de economische impact van dit scenario te bepalen is een literatuuronderzoek gedaan dat de in tabel 4 weergegeven uitkomsten geeft.

Internationaal vergelijken kan en moet overigens verder gaan dan het toegepaste onderzoek. Er valt veel te leren van internationale beleidsvergelijking, inclusief de voorbereiding van het beleid. Internationale vergelijking van onderzochte scenario's en hun economische impact is relevant als

7 Soms zijn vergelijkende studies ook mogelijk indien de effecten binnen een land op regionale of lokale schaal optreden. Voorbeelden zijn de studies van West en Lenze (1994) en Strobl (2011) naar de invloed van de megastormen in de Verenigde Staten en die van Glaeser en Shapiro (1992) naar de invloed van terrorisme in Israël. 
toets of men alle voor een all hazard-aanpak relevante risico's al in kaart heeft gebracht en om te bezien of de orde van grootte van de economische effecten in lijn ligt met wat voor andere landen is gevonden.

\section{Tabel 4: $\quad$ Evidentie grootschalige rellen (OECD-gebied)}

\begin{tabular}{|c|c|c|c|c|c|c|c|}
\hline & & \multirow[t]{2}{*}{ Duur } & \multirow[t]{2}{*}{ Doden } & \multirow[t]{2}{*}{$\begin{array}{l}\text { Gewon- } \\
\text { den }\end{array}$} & \multicolumn{2}{|c|}{$\begin{array}{l}\text { Schade, in miljoen euro en } \\
\text { prijzen van } 201 I \text { (wissel- } \\
\text { koers } 3 I / I 2 / I I \text { ) }\end{array}$} & \multirow[t]{2}{*}{ Totaal } \\
\hline & & & & & Materieel & Gezondheid & \\
\hline $\mathrm{VK}^{*}$ & 2001 & 6 weken & & 456 & 18 & 2 & 20 \\
\hline Miami & 1980 & 2 dagen & 17 & 400 & 62 & 5 & 67 \\
\hline Parijs & 2005 & 6 weken & 1 & n.b. & 220 & 0 & 220 \\
\hline LA & 1965 & I week & 34 & 1032 & 227 & 11 & 237 \\
\hline LA & 1992 & 3 dagen & 52 & 2500 & 552 & 21 & 573 \\
\hline Londen & 2010 & 4 dagen & 5 & 100 & 599 & I & 600 \\
\hline
\end{tabular}

* Dit betreft een serie opeenvolgende rellen in Bradford, Burnley en Oldham.

Bronnen: Bagguley en Hussain (2008), DiPasquale en Glaeser (1998), Goodwin, Pickup en De Rooij (20I2), Riots Communities and Victims Panel (20I2).

Het overzicht helpt de orde van grootte van de te verwachten economische impact te ramen. In het bijzonder zijn de volgende observaties daarbij van belang:

- Er is geen evident verband tussen duur en gebiedsgrootte van de rellen.

- De materiële schade in tabel 4 varieert tussen de 20 en 600 miljoen euro (prijzen van 2011, wisselkoersen ultimo 2011) en de modale waarde is 200 miljoen.

In het scenario wordt de materiële schade geschat op 200 tot 400 miljoen euro en de totale schade op 350 tot 660 miljoen euro.

\subsection{Modelberekeningen}

Een modelmatige analyse is nuttig, omdat dan onderzocht kan worden hoe de verschillende macro-economische grootheden worden beïnvloed door gedragingen van burgers en bedrijven. Nederland is rijk voorzien van macro-economische modellen die kunnen worden gebruikt bij ramingen van effecten met een nationale omvang. ${ }^{8}$ Het $\mathrm{CPB}$ publiceert deze modellen altijd in samenhang met variantentabellen ('spoorboekjes') die aangeven hoe de economie reageert op schokken in exogene variabelen. Een belangrijk voordeel is dat macro-econometrische modellen de belangrijkste economische samenhangen voor een volkshuishouding weergeven en dat doen voor een veelheid aan schokken. Nadeel is dat de desbe-

8 Modellen voor specifieke sectoren en segmenten worden onderhouden door onder andere het Economisch Instituut voor de Bouwnijverheid (EIB) en het Economisch Instituut Midden en Kleinbedrijf (EIM). 
treffende schokken in het verleden moeten zijn opgetreden en dat nieuwsoortige schokken dus niet kunnen worden geanalyseerd, tenzij ze kunnen worden herleid tot wel bekende macro-economische impulsen.

\section{Handvat: Exportdaling in CPB-model SAFFIER}

In het 'Cyberspionage'-scenario uit de NRB 2011 leidt onder meer diefstal van intellectueel eigendom en bedrijfsgeheimen tot een omvangrijke daling van de uitvoer van Nederland:

'De export valt met $10 \%$ terug met zo'n 19 miljard euro (= 3\% BBP). Nederland probeert op creatieve wijze deze onverwachte daling te bestrijden en is daar - zoals tijdens eerdere crises ook is gebleken best succesvol in.'

Aan de variantenanalyse (Centraal Planbureau 2011) kunnen de volgende gegevens worden ontleend voor een daling van de Nederlandse wereldhandel met $1 \%$.

\begin{tabular}{lccccc}
\hline $\begin{array}{l}\text { Cumulatieve } \\
\text { afwijking na }\end{array}$ & & $\mathbf{I}$ jaar & $\mathbf{2}$ jaar & $\mathbf{4}$ jaar & $\mathbf{8}$ jaar \\
\hline Bbp & $\%$ & $-0,2$ & $-0,3$ & $-0,3$ & $-0,2$ \\
Werkloosheid & $\%$ & 0,1 & 0,2 & 0,2 & 0,1 \\
EMU-saldo & $\% p t$ & $-0, I$ & $-0,2$ & $-0,2$ & $-0,2$ \\
\hline
\end{tabular}

De daling van de uitvoer tot een niveau $10 \%$ onder het niveau in het basisscenario komt dus neer op een daling van het nationaal product met $2 \%$ tot $3 \%$. In de variantenanalyse is herstel zichtbaar, omdat de afwijking na acht jaar kleiner is geworden.

\section{Robuustheid en gevoeligheid}

Modelberekeningen (en ramingen) laten dikwijls verschillende uitkomsten zien. Soms zijn deze uitkomsten niet helemaal consistent. Enerzijds kan dit door beleidsmakers worden ervaren als een probleem, omdat zij het beleid liever baseren op één uitkomst (namelijk de meest betrouwbare of meest waarschijnlijke uitkomst). Anderzijds is het juist nuttig om te weten hoe groot de spreiding van de modeluitkomsten is, omdat alleen de waaier van uitkomsten inzicht biedt in de onzekerheid die de ramingen omgeeft. Het is verstandig die onzekerheid niet te verdoezelen. De eerder besproken casus 'Ernstige grieppandemie' laat twee berekeningswijzen los op hetzelfde probleem. De verschillende uitkomsten geven inzicht in de onzekerheid van de economische ramingen. De raming van de eco- 
nomische effecten voor dit grieppandemiescenario is in de NRB weergegeven als een interval van 700 miljoen tot 5 miljard euro (Mennen 2012).

Een belangrijke reden voor de verschillen tussen modeluitkomsten is dat het modelleren van rampen maatwerk is. Sommige economische aspecten komen beter tot hun recht in het ene model dan in het andere. Als de aandacht bijvoorbeeld uitgaat naar de onderlinge leveringen binnen (inter)nationale waardeketens, dan is de input-outputbenadering aangewezen. Wil men een indicatie voor de rijksfinanciën, dan zijn structurele modellen het meest geschikte gereedschap. Aanpassings- en weerstandsvermogen komen beter tot hun recht in toegepaste algemeen-evenwichtmodellen. Okuyama $(2007,122)$ geeft als vuistregel om de input-outputresultaten als bovengrens en de algemeen-evenwichtuitkomsten als ondergrens te gebruiken voor de raming van het interval waarbinnen de uitkomst moet liggen. Door het combineren van verschillende methoden ontstaat beter inzicht in de robuustheid van de raming en van de effecten van aannames en parameters die de uitkomst bepalen.

Ook als de cijfers ondubbelzinnig zijn, moeten de modeluitkomsten dikwijls nader worden geïnterpreteerd. Een belangrijke factor die bijvoorbeeld bepaalt hoe groot de uiteindelijke maatschappelijke kosten zijn die worden veroorzaakt door de nationale veiligheidsrisico's, is het weerstandsvermogen van de economie (Rose 2004). Hoe flexibeler de mensen, markten en bedrijven, des te geringer is de schade en des te sneller treedt herstel op. Het weerstandsvermogen is daarom een belangrijke factor in het risicomanagement en bij de inschatting van de maatschappelijke kosten. ${ }^{9}$

In economische termen gaat het bij weerstandsvermogen om het aanpassingsvermogen en daarmee om de mogelijkheden voor substitutie en de flexibiliteit van de economie (zowel van de arbeids- als de productmarkten). Het feit dat een bepaalde waardeketen wordt verstoord, heeft minder impact indien consumenten alternatieve producten en diensten kunnen kiezen en/of bedrijven op een andere manier kunnen werken. Een tekortschietende productie kan soms worden opgevangen door langer te werken op de resterende productiefaciliteiten. Onderbezetting (een tekort aan arbeid) leidt over kortere perioden zelden tot groot productieverlies. Dergelijke factoren dragen bij aan het weerstandsvermogen.

\section{Slot}

Sinds het midden van de jaren negentig van de vorige eeuw is er sprake van een opmerkelijke groei van het onderzoek naar de effecten van rampen. Er is inmiddels veel ervaring opgedaan met een breed palet aan onderzoekstechnieken, maar in het Nederlandse economische onderzoek is de economische invloed van rampen tot nu toe onderbelicht gebleven. Deze literatuurstudie biedt een overzicht op hoofdlijnen van beschikbare buitenlandse en binnenlandse methodieken en van de voor- en nadelen van deze methodieken, met als doel handvatten te bieden

9 Het is belangrijk weerstandsvermogen en kwetsbaarheid goed te onderscheiden. Een hoog inkomensniveau maakt kwetsbaar omdat een incident een grotere impact kan hebben, maar kan anderzijds het weerstandsvermogen vergroten (Kellenberg \& Mobarak 2010). 
om de economische impact van rampen in het stellen van preventieprioriteiten mee te wegen. Een belangrijke conclusie is dat het in principe mogelijk is om met deze methodieken de potentiële kosten van een groot scala aan nationale veiligheidsrisico's te bepalen (we maken wel een voorbehoud ten aanzien van macroeconometrische modellen). Economen kunnen volgens ons dus een zinvolle bijdrage leveren aan de all hazard-benadering die in de NRB wordt voorgestaan. De economische invalshoek kan beleidsmakers en analisten helpen om goede afwegingen te maken aangaande investeringen in capaciteiten ter preventie van rampen en crises, het uiteindelijke doel van de strategie Nationale Veiligheid.

Het aantal wetenschappelijke studies dat consequent een all hazard- (of beter gezegd: multi hazard-) benadering toepast, is nog steeds gering. Te noemen zijn de studies van Nahuis (2001), Tavares (2004) en Shaw (2011), die dit concept impliciet of expliciet toepassen, gezien de waaier aan rampen die wordt onderzocht door deze auteurs. We hebben met concrete voorbeelden getoond dat een economische benadering in het kader van een all hazard-raamwerk mogelijk is. Economische methoden zijn immers in dit artikel op alle domeinen van de nationale veiligheid toegepast en aan de besproken studies kunnen over het algemeen en op macroniveau voldoende inzichten worden ontleend om de potentiële schade te ramen, zoals ook al in concrete scenario's uit de NRB is gebleken. Bij sector- of regiospecifieke veiligheidsrisco's zal steeds maatwerk geboden moeten worden; hier geven de besproken bevindingen echter wel een indicatie om de orde van grootte te toetsen.

Het ligt in de lijn der verwachting dat het palet aan beschikbare ramingstechnieken in de toekomst verder zal verbreden. In die zin is deze notitie niet alleen relevant als een beschrijving van de stand van zaken, maar beoogt ze ook een startpunt te zijn voor nader onderzoek. In het kader van de NRB is vooral een eerste, op microdata gebaseerde all hazard-benadering gewenst, omdat hiermee zowel in binnen- als buitenland nog geen ervaring is opgedaan.

\section{Literatuur}

Alexander, D. (1997) The Study of Natural Disasters, 1977-1997. Some Reflections on a Changing Field of Knowledge. Disasters, 21(4), 284-304.

Bagguley, P. \& Y. Hussain (2008) Riotous Citizens. Ethnic Conflict in Multicultural Britain. Ashgate.

Barro, R.J. \& T. Jin (2009) On the Size Distribution of Macroeconomic Disasters (NBER Working Paper 15247). Cambridge, MA: NBER.

Bergeijk, P.A.G. van \& S. Lazzaroni (2013) Macroeconomics of Natural Disasters. Meta analysis and policy options (werkdocument). Harvard Center for Risk Analysis. www.hsph .harvard.edu/hcra/files/2013/09/Bergeijk-Lazzaroni-Sept.-2013.pdf.

Centraal Planbureau (2011) Varianten Saffier II.CPB onderzoeksmemorandum.www.cpb.nl/ publicatie/varianten-saffier-ii.

Cole, S. (1995) Lifelines and Livelihood a Social Accounting Matrix Approach to Calamity Preparedness. Journal of Contingencies and Crisis Management, 3(4), 228-240.

Congressional Budget Office (2006) A Potential Influenza Pandemic. Possible Macro-economic Effects and Policy Issues. Washington: CBO. 
DiPasquale, D. \& E.L. Glaeser (1998) The Los Angeles Riot and the Economics of Urban Unrest. Journal of Urban Economics, 43(1), 52-78.

Glaeser, E.L. \& J.M. Shapiro (2002) Cities and Warfare. The Impact of Terrorism on Urban Form. Journal of Urban Economics, 51(2), 205-224.

Goodwin, M., M. Pickup \& E.A. de Rooij (2012) Perceived Threat, Ethnic Minority Prejudice and the Riots in England (paper jaarvergadering APSA).

Greenberg, M.R., M. Lahr \& N. Mantell (2007) Understanding the Economic Costs and Benefits of Catastrophes and Their Aftermath. A Review and Suggestions for the U.S. Federal Government. Risk Analysis, 27(1), 83-96.

Hyndman, D. \& D. Hyndman (2006) Natural Hazards and Natural Disasters. Belmont: Brooks.

Kellenberg, D.K. \& A.M. Mobarak (2008) Does Rising Income Increase or Decrease Damage Risk from Natural Disasters? Journal of Urban Economics, 63, 788-802.

Kim, C.-K. (2010) The Effects Of Natural Disasters On Long-Run Economic Growth. The Michigan Journal of Business, 41, 15-49.

Larsen, S. (2011) Tourism in a Decade of Terrorism, Disasters and Threats. Some Lessons Learned. Scandinavian Journal of Hospitality and Tourism, 11(3), 215-223.

Li, Q. (2006) Political Violence and Foreign Direct Investment. In: M. Fratianni (ed.), Regional Economic Integration, Research in Global Strategic Management Volume 12. Amsterdam: Elsevier North Holland, 225-250.

Loayza, N., E. Olaberría, J. Rigolini \& L. Christiaensen (2009) Natural Disasters and Growth: Going beyond the Averages (World Bank Policy Research Paper WPS4980). Washington D.C.: World Bank.

Lugnèr, A.K., M. van Boven, R. de Vries, M.J. Postma \& J. Wallinga (2012) Cost Effectiveness of Vaccination against Pandemic Influenza in European Countries. Mathematical Modelling Analysis. BMJ, 12(345), e4445.

Mennen, M.G. (red.) (2012) Nationale Risicobeoordeling 2011. Bilthoven: RIVM, Analistennetwerk Nationale Veiligheid.

Mennen, M.G. (red.) (2013) Nationale Risicobeoordeling 2012. Bilthoven: RIVM, Analistennetwerk Nationale Veiligheid.

Ministerie van Binnenlandse Zaken en Koninkrijksrelaties (2007) Nationale veiligheid. Strategie en werkprogramma 2007-2008. Den Haag: Ministerie van BZK.

Ministerie van Binnenlandse Zaken en Koninkrijksrelaties (2009) Werken met scenario's, risicobeoordeling en capaciteiten in de strategie Nationale Veiligheid. Leidraad NRB methodiek. Den Haag: Ministerie van BZK.

Möhlmann, J. (2013) Globalization and Productivity. Micro-evidence on Heterogeneous Firms, Workers and Products (proefschrift Vrije Universiteit Amsterdam).

Mueller, J. \& M.G. Stewart (2011) Terror, Security, And Money. Balancing The Risks, Benefits, And Costs Of Homeland Security (paper for the Annual Convention of the Midwest Political Science Association, Chicago).

Nahuis, N.J. (2001) De conjuncturele gevolgen van rampen. ESB, 4330, 800-803.

Nitsch, V. \& D. Schumacher (2004) Terrorism and International Trade. An Empirical Investigation. European Journal of Political Economy, 20(2), 423-433.

Okuyama, Y. (2007) Economic Modelling for Disaster Impact Analysis. Past, Present and Future. Economic Systems Research, 19(2), 115-124.

Okuyama, Y. \& S.E. Chang (eds.) (2004) Modelling Spatial and Economic Impacts of Disasters. Berlijn/Heidelberg/New York: Springer.

Okuyama, Y., G.J.D. Hewings \& M. Sonis (2002) Measuring Economic Impacts of Disasters. Interregional Input-Output Analysis Using Sequential Interindustry Model. In: Y. 
Okuyama \& S.E. Chang (eds.), Modelling Spatial and Economic Impacts of Disasters. Berlijn/Heidelberg/New York: Springer, 77-102.

Pellinga, M., A. Özerdemb \& S. Barakatb (2002) The Macro-economic Impact of Disasters. Progress in Development Studies, 2(4), 283-305.

Popp, A. (2006) The Effects of Natural Disasters on Long Run Growth. Major Themes in Economics, voorjaar, 61-82.

Riots Communities and Victims Panel (2012) After the Riots, Final report. Londen.

Romijn, G. \& G. Renes (2013) Algemene leidraad voor maatschappelijke kosten-batenanalyse. Den Haag: CPB/PBL.

Rose, A. (2004) Defining and Measuring Economic Resilience to Disasters. Disaster Prevention and Management, 13(4), 307-314.

Rose, A., J. Benavides, S.E. Chang, P. Szczeniak \& D. Lim (1997) The Regional Economic Impact of an Earthquake: Direct and Indirect Effects of Electricity Lifeline Disruptions. Journal of Regional Science, 37(3), 437-458.

Sahin, S. (2011) Estimation of Disasters' Economic Impact in 1990-2007. Global Perspectives. Mimeo.

Santos, J.R. (2006) Inoperability Input-Output Modeling of Disruptions to Interdependent Economic Systems. Systems Engineering, 9(1), 20-34.

Santos, J.R. \& Y.Y. Haimes (2004) Modelling the Demand Input Output (I-O) Demand Inoperability due to Terrorism of Interconnected Infrastructures. Risk Analysis, 24(1), 1437-1451.

Shaw, W.T. (2011) The 2011 Tohoku, Japan Quake and Tsunami. Provisional Financial Impact Assessment. Mimeo. University College London, http://dx.doi.org/10.2139/ssrn. 1797845.

Strobl, E. (2011) The Economic Growth Impact of Hurricanes. Evidence From U.S. Coastal Counties. The Review of Economics and Statistics, 93(2), 575-589.

Tavares, J. (2004) The Open Society Assesses its Enemies. Shocks, Disasters and Terrorist Attacks. Journal of Monetary Economics, 51, 1039-1070.

Veen, A. van der (2004) Disasters and Economic Damage. Macro, Meso and Micro Approaches. Disaster Prevention and Management, 13(4), 274-279.

West, C.T. \& D.G. Lenze (1994) Modeling the Regional Impact of Natural Disaster and Recovery: A General Framework and an Application to Hurricane Andrew. International Regional Science Review, 17, 121-150.

Yang, D. (2006) Coping With Disaster. The Impact Of Hurricanes On International Financial Flows, 1970-2002 (NBER Working Paper 12794). Cambridge, MA: NBER. 